\title{
A Comparative Evaluation of Manual Small Incision Cataract Surgery and Phacoemulsification with Rigid Posterior Chamber Intraocular Lens
}

\author{
Rajender Singh Chauhan", Apoorva Goel, Himanshu Bhatnagar, Ashok Rathi
}

Regional Institute of Ophthalmology, PGIMS, Rohtak, Haryana, India

\author{
DOI: $\underline{10.36348 / \text { simps.2020.v06i04.005 }}$ \\ | Received: 07.04.2020 | Accepted: 14.04.2020 | Published: 24.04.2020
}

*Corresponding author: Rajender Singh Chauhan

\section{Abstract}

This study was conducted at a tertiary care eye hospital to evaluate and compare the two techniques of sutureless cataract surgeries which are manual small incision cataract surgery and phacoemulsification with rigid posterior chamber intraocular lens with respect to surgically induced astigmatism, operative and postoperative complications and best corrected visual acuity at the end of 8 weeks. The study was carried out on 100 patients who were divided into 2 groups with group A undergoing MSICS with rigid PCIOL and group B undergoing phacoemulsification with rigid PCIOL. Postoperative evaluation was done till 3 months. The mean surgically induced astigmatism in group A was higher than that in group B. Operative complications were seen in $6 \%$ of group A as compared to $8 \%$ in group B. The overall postoperative complication rate in the study was $8 \%$. Hence, both the surgeries have almost similar outcome in terms of final visual acuity, astigmatism and complications.

Keywords: Cataract, phacoemulsification, manual small incision cataract surgery, astigmatism, posterior chamber intraocular lens, complications.

Copyright @ 2020: This is an open-access article distributed under the terms of the Creative Commons Attribution license which permits unrestricted use, distribution, and reproduction in any medium for non-commercial use (NonCommercial, or CC-BY-NC) provided the original author and source are credited.

\section{INTRODUCTION}

Phacoemulsification and manual small incision cataract surgery (MSICS) are the two most popular methods of cataract surgery today. Phacoemulsification and manual small incision cataract surgery represent significant advancement over the older techniques of cataract surgery, both in terms of post-operative outcome and patient comfort. Phacoemulsification was developed in the sixties but gained popularity in the nineties only when better machines became available. Although, both methods have a longer learning curve than conventional extracapsular cataract extraction (ECCE) and put greater demands on the surgeon in terms of skill and instrumentation, these methods have gained wide acceptance and have become necessary skills for the modern ophthalmic surgeon to master.

After performing successful ECCE with posterior chamber intraocular lens (PCIOL) surgery, surgeons face the problem of surgically induced astigmatism. Scleral tunnel incision in cataract surgery has reduced postoperative astigmatism besides increased intraoperative safety, decreased postoperative inflammation and pain [1].
The corneal deformation caused by the surgery usually leads to postoperative astigmatism. This can be defined as a condition in which incident rays of light are not refracted equally in all meridians. Thus, the refractive power of eyes varies with the orientation of light rays. Usually the axes of greatest and least refractive power can be determined. These are called principle or major meridians. Astigmatism is said to be regular if the principle meridia are approximately $90^{\circ}$ and irregular if they are not or if the major meridia can't be identified [1]. The most common astigmatism is one with the vertical curvature of cornea being more than the horizontal curvature. This is known as the direct or with- the- rule astigmatism. This type of astigmatism is accepted as physiological as it is due to constant pressure of upper eyelid upon the eye. When the horizontal curvature is more than vertical curvature, then it is called inverse or against- the rule- astigmatism [2]. If the principle meridian is more than $20^{\circ}$ from the vertical or horizontal, the astigmatism is said to be oblique. Suture induced astigmatism is the difference between preoperative and postoperative keratometric readings with the sutures still in place. Suture induced astigmatism arise from suture tension, tissue edema and underlying surgically induced astigmatism. Surgically induced astigmatism is the difference between 
preoperative and postoperative values after all sutures have been removed. This value is more accurate reflection of the actual amount of astigmatism produced by a surgical procedure. Surgically induced astigmatism arises from the incision, its realignment and wound healing [1].

\section{Pathophysiology of Postoperative Astigmatism}

The primary causes of postoperative astigmatism following cataract surgery are wound compression, wound gaping and wound misalignment.

\section{Wound Compression}

In case of superior incision, wound compression creates a steep vertical meridian, and at the same time, a flat horizontal meridian. Therefore, wound compression leads to with- the- rule astigmatism in superior incision. Wound compression is typically produced by fine sutures such as 10-0 nylon and 9-0 silk, mid to close relatively anterior incision, deeply inserted sutures, wide suture bites, greater number of sutures and tight sutures which can arise both from over tightening at the time of surgery and postoperative tissue edema. Both absorbable and non- absorbable sutures can produce wound compression $[3,4]$. This is a usual finding in immediate postoperative period. A tight suture causes an inversion of the wound edges that results in an in-folding of cornea, a decrease in radius of curvature and cord length in the meridian of the suture and a compensatory steepening in the center of cornea. In the area of suture, the cornea is flattened. Steepening of the meridian containing the tight sutures causes a secondary flattening of the perpendicular meridian $[4$, $5]$.

\section{Wound Gaping}

Wound gaping and stretching are associated with permanent surgically induced against- the ruleastigmatism which is induced with absorbable and nonabsorbable sutures. These sutures can't be placed deeply as they cause tissue necrosis, formation of fibrovascular tissue, epithelialization of the suture tract and fistula formation [6]. Thus, the wound must be closed in less than full depth as this creates a posterior wound gap regardless of how tightly sutures are tied and this gap may persist upto 23 years [6-8]. Partial thickness fibrovascular scar causes delayed wound healing and stretches and flattens thus increasing corneal radius in the affected meridian and causing against- the rule- astigmatism [9]. The knots of these sutures may slip or the sutures may loosen, erode or degrade, thus failing to support the inadequately closed wound long enough for healing to take place [10]. Posterior wound gape may also result if nylon is placed loosely or superficially or if they are removed prematurely $[4,6]$. In addition to posterior wound gape, anterior wound gape can also produce against- the- rule astigmatism. This may be caused by loosely or deeply placed sutures [7].

\section{Wound Misalignment}

It is typically associated with permanent, suture induced astigmatism [11]. Astigmatism may be induced in any axis and depends on nature and location of the defects. The wound may be misaligned vertically by poor surgical technique or by sutures of an unequal depth on either side, producing an override or underride. This usually results in corneal steeping because the corneal radius of curvature is shortened in the affected meridian. However, it may also result in flattening if the resultant wound is too thin and stretches during the postoperative period.

\section{Measurement of Corneal Astigmatism}

The classic methods for measuring corneal astigmatism are refraction and keratometry. Recently, there has been increased interest in keratometric measurement as well. The keratometer directly measures the radius of curvature of the anterior corneal surface over a central $3 \mathrm{~mm}$ area. They also provide a corresponding refractive power in diopters, for any measured meridian. The magnitude of the corneal astigmatism is the difference in diopters between the refractive powers of the principal meridian. Both preoperative and postoperative measurements are necessary in order to determine the amount of astigmatism produced by surgical procedure [1]. In order to evaluate the effect of the surgical procedure on the central corneal shape, not only the magnitude but also the axes of the major meridian must be considered. Calculation of vector corrected astigmatism is the preferred method for determining the effect of a surgical procedure upon the corneal curvature [12].

\section{Phacoemulsification}

The problem of postoperative astigmatism which is caused by longer incision and suturing of surgical wound has compelled ophthalmic surgeons to develop a technique that could facilitate cataract through a small sutureless incision. It permits the removal of cataract through a small incision of $3 \mathrm{~mm}$, thus eliminating many of the complications of wound healing related to large incision cataract surgery that is shortening of recovery period and post- surgical astigmatism to minimum [13]. Postoperative astigmatism values after surgery using a 6-7 $\mathrm{mm}$ Sclera tunnel are lower than those using limbal and corneal incision [14, 15]. Astigmatism increases when the incision approaches from the sclera to the limbus or cornea. However, when the corneal incision is reduced, the effect of the astigmatism is less and at least as low as that seen in scleral incisions [16].

In the early development of phacoemulsification, incisions were made at the superior or supero-temporal meridian. It was soon realized that the supra orbital ridge limits the maneuverability of the phaco probe, making the procedure technically difficult. So most surgeons have 
shifted the site from superior to temporal. Temporal approach provides better exposure during the surgery and natural drainage of fluid from temporal canthus. It results in rapid stabilization of astigmatism and early visual recovery. In this position, fundal red glow is brighter so continuous curvilinear capsulorhexis can be done easily $[17,18]$.

\section{Small Incision Cataract Surgery}

The Sclera tunnel incision was introduced in the early eighties in an attempt to provide better wound healing with less surgically induced astigmatism. This became the most favored incision technique in the recent past for sutureless, small incision, non- phaco cataract surgery. The classical incision is a three- step incision shaped like a Z [19]. This incision begins with a scleral groove, continues with a scleral tunnel, progresses slightly into the cornea and then forms a corneal lip before entering the anterior chamber. This incision is self sealing because pressure in the anterior chamber automatically pushes the lip against the intracorneal portion of the incision sealing it tightly without sutures [20].

\section{Material AND MethodS}

This study was conducted at Regional Institute of Ophthamalology, Pt. B. D. Sharma PGIMS, Rohtak and comprised of 100 patients of immature senile cataract. The patients were randomly and equally divided into group A and group B. In group A small incision cataract surgery with PCIOL implantation was performed while in Group B, phacoemulsification with rigid posterior chamber intraocular lens was carried out. In both the groups, a superior scleral tunnel incision was made and no sutures were applied.

All surgeries were performed by same surgeon under local (peribulbar) anesthesia, using $5 \mathrm{ml}$ of $2 \%$ lignocaine, $5 \mathrm{ml}$ of $0.5 \%$ bupivacaine, and $125 \mathrm{IU}$ of hyaluronidase.

All the patients were subjected to history taking and examination as per the patient proforma.

\section{Exclusion Criteria}

1. Corneal opacities/lesions/previous corneal surgery

2. History of previous intraocular surgery

3. Cataracta brunescens/rubra/niagra

4. Subluxated/dislocated lens

5. Exfoliation syndrome

6. High myopia/hypermetropia

7. Any history of uveitis

8. Patients of diabetes mellitus and/or hypertension

9. Patients having any posterior segment disease

\section{Pre-Operative Preparation}

1. A written and informed consent was taken before surgery.

2. The patient was kept nil per oral for two hours prior to surgery.

3. The eye to be operated was marked and prepared for surgery.

\section{Local Treatment}

1. Povidone iodine (1:10) solution instilled TDS a day before surgery.

2. Ciprofloxacin eye drops instilled TDS a day before surgery.

3. Flurbiprofen and ciprofloxacin eye drops instilled every half hour for 2 hours before surgery.

4. Tropicamide $(0.8 \%)$ with phenylephrine $(5 \%)$ eye drops instilled every 15 minutes 2 hours before surgery.

5. Painting of half of the face, nose and forehead, along with the lids with $5 \%$ povidone iodine solution was done.

6. Irrigation of conjunctival cul-de-sac with 1:10 solution of povidone iodine solution was done.

\section{Operating Steps}

1. Under full asepsis, peribulbar anesthesia was given.

2. A superior rectus bridle suture and a universal eye speculum were applied.

3. A fornix based conjunctival flap was raised.

4. A $6.0 \mathrm{~mm}$ frown incision was made by razor blade fragment $1.5 \mathrm{~mm}$ behind the limbus.

5. A $6.0 \mathrm{~mm}$ scleral tunnel was made superiorly with the help of a crescent knife reaching 1.5 $\mathrm{mm}$ into the cornea.

6. Side port entry was made.

7. The anterior chamber was entered with a $3 \mathrm{~mm}$ keratome, and formed with sterile air.

8. 2 drops of trypan blue dye were instilled under the sterile air bubble in the chamber to stain the anterior capsule. The dye and the air were replaced with $2 \%$ methylcellulose.

9. Continuous curvilinear capsulorrhexis was done using a double bent $26 \mathrm{G}$ needle and hydrodissection and hydrodelineation were achieved by injecting ringer lactate solution through a hydrodissection cannula.

10. In group A (MSICS), the nucleus was rotated and prolapsed into the anterior chamber, and then delivered out using an irrigating wire vectis/ visco expression. The remaining cortical matter was aspirated using a Simcoe`s 2-way I\&A cannula.

11. In group B (phacoemulsification), the nucleus was emulsified and aspirated by using a phaco probe. The cortical matter was aspirated using automated irrigation-aspiration probe. 
12. A rigid PCIOL was implanted in the capsular bag in both groups.

13. Conjunctival flap was reposited back and anchored with the help of wet field cautery.

\section{Postoperative Evaluation}

Post- operative evaluation was done 1 day, 1 week, 6 weeks and 3 months post- operatively, and included a detailed examination including vision, keratometry, slit lamp biomicroscopy, and intra ocular pressure measurement.

Parameters for comparison were as follows:

1. Pre-operative- Visual acuity, grade of cataract, keratometry, intra-ocular pressure by Applanation tonometer

2. Operative - duration of surgery, complications, phaco time (in group B), amount of fluid used (in group B)

3. Post-operative: follow up was done on $1^{\text {st }}$ day, 1 week, 3 weeks, 6 weeks, and 8 weeks. The following parameters were ascertained:
a. Visual acuity,
b. Slit lamp examination of lids, conjunctiva, cornea, anterior chamber, pupil, iris, and IOL
c. Intra-ocular pressure by applanation tonometer
d. Keratometry
e. Fundus examination
f. Astigmatism calculation

The change in astigmatism was calculated at each follow up and the occurrence of post-operative complications noted.
The cylinder was taken as the difference of vertical and horizontal K-readings (pre-operative and post-operative), with the axis of the higher K-reading. This was then converted to Cartesian coordinates using the following formula:

$$
\begin{aligned}
& \mathrm{X}=\text { cylinder*cos }(2 * \text { axis }) \\
& \mathrm{Y}=\text { cylinder } * \operatorname{sine}(2 * \text { axis })
\end{aligned}
$$

Pre-operative Cartesian coordinates were subtracted from the postoperative values, and the difference was taken as $\mathrm{X}$ and $\mathrm{Y}$ respectively. To convert the Cartesian coordinates back to standard notation for astigmatism, the following formula was used $[6,2]$ :

$$
\begin{aligned}
& \text { Cylinder }=\sqrt{ } \mathrm{X}^{2}+\mathrm{Y}^{2} \\
& \text { Angle }=1 / 2 * \operatorname{Arc} \tan (\mathrm{Y} / \mathrm{X}) \\
& \text { If } \mathrm{X} \& \mathrm{Y}>0 \text {, then axis }=\text { angle } \\
& \text { If } \mathrm{X}<0 \text {, then axis }=\text { angle }+90^{\circ} \\
& \text { If } \mathrm{X}>\mathrm{O} \& \mathrm{Y}<0 \text {, then axis }=\text { angle }+180^{\circ} \\
& \text { Mean of } \mathrm{X}=\sum_{i=1}^{n} X i / n \\
& \text { Mean of } \mathrm{Y}=\sum_{i=1}^{n} Y i / n
\end{aligned}
$$

\section{ObServations}

Our study included 100 patients of cataract who were randomly and equally divided into two groups $\mathrm{A}$ and $\mathrm{B}$ of 50 patients each. In patients of Group A, manual small incision cataract surgery with rigid posterior chamber intraocular lens was carried out while in Group B, phacoemulsification with rigid posterior chamber intraocular lens was carried out.

Table-1: Distribution of preoperative astigmatism in patients

\begin{tabular}{|l|l|l|}
\hline Groups (no. of patients) & Group A & Group B \\
\hline With the rule & 27 & 26 \\
\hline No astigmatism & 9 & 13 \\
\hline Against the rule & 14 & 11 \\
\hline Total & 50 & 50 \\
\hline
\end{tabular}

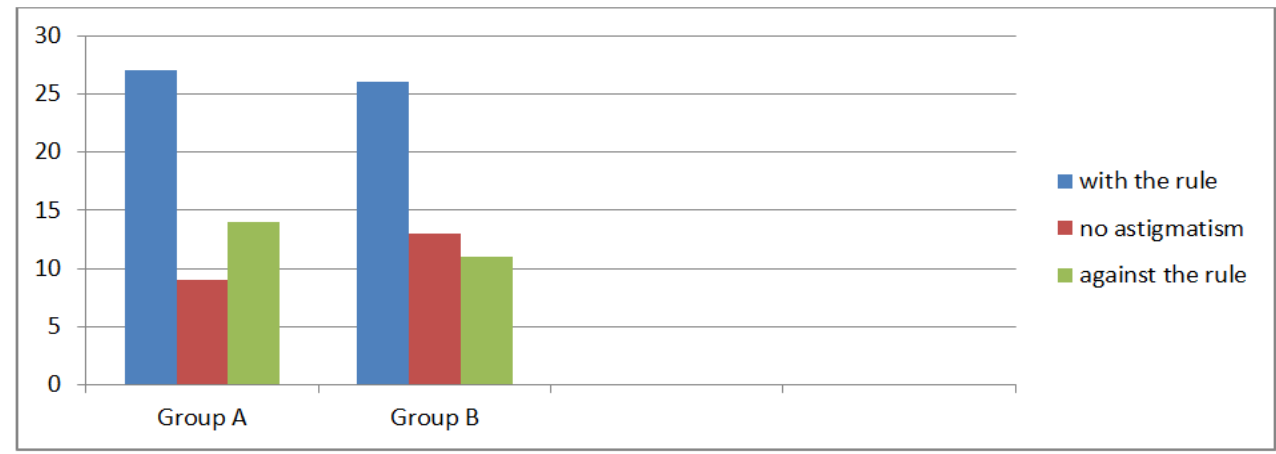

Fig-1: Distribution of preoperative astigmatism in patients

Table-1 and Figure-1 shows that in group A, 27 patients had with- the- rule astigmatism, 9 patients had no astigmatism and 14 patients had against- the- rule astigmatism. In group B, 26 patients had with- therule astigmatism, 13 patients had no astigmatism and 11 patients had against- the- rule astigmatism. 
Table-2: Distribution of preoperative astigmatism in patients in group $A$ and group $B$

\begin{tabular}{|l|l|l|l|l|}
\hline \multirow{2}{*}{ Astigmatism (Dioptre) } & Group A & Group B \\
\cline { 2 - 5 } & With- the- rule & Against- the- rule & With- the- rule & Against- the- rule \\
\hline$\leq 0.5$ & 10 & 3 & 9 & 3 \\
\hline $0.5-1.0$ & 8 & 5 & 6 & 4 \\
\hline $1.0-1.5$ & 3 & 4 & 4 & 3 \\
\hline $1.5-2.0$ & 4 & 1 & 5 & 1 \\
\hline$>2.0$ & 2 & 1 & 2 & 0 \\
\hline Total & 27 & 14 & 26 & 11 \\
\hline
\end{tabular}

Table-2 shows that the mean preoperative astigmatism in group $\mathrm{A}$ in the with- the- rule subgroup was $+0.98 \pm 0.68 \mathrm{D}$ while it was $-1.12 \pm 0.61 \mathrm{D}$ in the against- the- rule subgroup. 9 patients were astigmatically neutral. The mean preoperative astigmatism in group $\mathrm{B}$ in the with- the- rule subgroup was $+1.09 \pm 0.72 \mathrm{D}$ while it was $-0.93 \pm 0.46 \mathrm{D}$ in the against- the- rule subgroup. 11 patients were astigmatically neutral.

Table-3: Postoperative astigmatism in group $A$ and group $B$ at the end of 8 weeks

\begin{tabular}{|c|c|c|c|c|c|c|}
\hline \multirow{2}{*}{$\begin{array}{l}\text { Astigmatism } \\
\text { (Diopter) }\end{array}$} & \multicolumn{3}{|l|}{ Group A } & \multicolumn{3}{|l|}{ Group B } \\
\hline & $\begin{array}{l}\text { Patients with } \\
\text { preoperative } \\
\text { with- the- rule } \\
\text { astigmatism }\end{array}$ & $\begin{array}{l}\text { Patients with no } \\
\text { preoperative } \\
\text { astigmatism }\end{array}$ & $\begin{array}{l}\text { Patients with } \\
\text { preoperative } \\
\text { against- the- rule } \\
\text { astigmatism }\end{array}$ & $\begin{array}{l}\text { Patients with } \\
\text { preoperative } \\
\text { with- the- rule } \\
\text { astigmatism }\end{array}$ & $\begin{array}{l}\text { Patients with } \\
\text { no preoperative } \\
\text { astigmatism }\end{array}$ & $\begin{array}{l}\text { Patients with } \\
\text { preoperative } \\
\text { against- the- rule } \\
\text { astigmatism }\end{array}$ \\
\hline$\leq 0.5$ & 8 & 0 & 0 & 9 & 0 & 0 \\
\hline $0.5-1.0$ & 11 & 2 & 0 & 6 & 4 & 0 \\
\hline $1.0-1.5$ & 5 & 4 & 3 & 6 & 5 & 0 \\
\hline $1.5-2.0$ & 3 & 3 & 2 & 4 & 3 & 4 \\
\hline$>2.0$ & 0 & 0 & 9 & 1 & 1 & 7 \\
\hline Total & 27 & 9 & 14 & 26 & 13 & 11 \\
\hline
\end{tabular}

Table-3 shows that the mean postoperative astigmatism in group $\mathrm{A}$ in patients with preoperative with- the- rule astigmatism was $-0.88 \pm 0.52 \mathrm{D}$, in Patients with no preoperative astigmatism it was $-1.42 \pm$ $0.39 \mathrm{D}$ while in Patients with preoperative against- therule astigmatism it was $-1.42 \pm 0.39 \mathrm{D}$. The mean postoperative astigmatism in group B in patients with preoperative with- the- rule astigmatism was $-1.02 \pm$ $0.63 \mathrm{D}$, in Patients with no preoperative astigmatism it was $-1.40 \pm 0.46 \mathrm{D}$ while in Patients with preoperative against- the- rule astigmatism it was $-2.52 \pm 0.65 \mathrm{D}$.

Table-4: Surgically induced astigmatism in group A and group B at the end of 8 weeks

\begin{tabular}{|c|c|c|c|c|c|c|}
\hline \multirow{2}{*}{$\begin{array}{l}\text { Astigmatism } \\
\text { (Diopter) }\end{array}$} & \multicolumn{3}{|l|}{ Group A } & \multicolumn{3}{|l|}{ Group B } \\
\hline & $\begin{array}{l}\text { Patients with } \\
\text { preoperative } \\
\text { with- the- rule } \\
\text { astigmatism }\end{array}$ & $\begin{array}{l}\text { Patients with no } \\
\text { preoperative } \\
\text { astigmatism }\end{array}$ & $\begin{array}{l}\text { Patients with } \\
\text { preoperative } \\
\text { against- the- rule } \\
\text { astigmatism }\end{array}$ & $\begin{array}{l}\text { Patients with } \\
\text { preoperative } \\
\text { with- the- rule } \\
\text { astigmatism }\end{array}$ & $\begin{array}{l}\text { Patients with no } \\
\text { preoperative } \\
\text { astigmatism }\end{array}$ & $\begin{array}{l}\text { Patients with } \\
\text { preoperative } \\
\text { against- the- rule } \\
\text { astigmatism }\end{array}$ \\
\hline$\leq 0.5$ & 0 & 0 & 0 & 0 & 0 & 0 \\
\hline $0.5-1.0$ & 4 & 1 & 0 & 2 & 4 & 0 \\
\hline $1.0-1.5$ & 18 & 5 & 6 & 13 & 4 & 7 \\
\hline $1.5-2.0$ & 3 & 2 & 8 & 8 & 2 & 2 \\
\hline$>2.0$ & 2 & 1 & 0 & 3 & 3 & 2 \\
\hline Total & 27 & 9 & 14 & 26 & 13 & 11 \\
\hline
\end{tabular}

Table-4 shows that the mean surgically induced astigmatism in group $\mathrm{A}$ in patients with preoperative with- the- rule astigmatism was $1.40 \pm$ $0.30 \mathrm{D}$, in Patients with no preoperative astigmatism it was $1.42 \pm 0.39 \mathrm{D}$ while in Patients with preoperative against- the- rule astigmatism it was $1.39 \pm 0.23 \mathrm{D}$. The mean postoperative astigmatism in group $\mathrm{B}$ in patients with preoperative with- the- rule astigmatism was $1.6 \pm$ $0.40 \mathrm{D}$, in Patients with no preoperative astigmatism it was $1.5 \pm 0.55 \mathrm{D}$ while in Patients with preoperative against- the- rule astigmatism it was $1.59 \pm 0.26 \mathrm{D}$.
Table-5: Operative complications in group $A$ and group B

\begin{tabular}{|l|l|l|}
\hline \multirow{2}{*}{ Nature of complications } & \multicolumn{2}{|c|}{ Number of patients } \\
\cline { 2 - 3 } & Group A & Group B \\
\hline Superficial tunnel & 0 & 0 \\
\hline Premature AC entry & 1 & 1 \\
\hline Descemet's detachment & 0 & 0 \\
\hline Iris prolapsed & 0 & 0 \\
\hline Extended capsulorrhexis & 1 & 1 \\
\hline Posterior capsular rent & 1 & 1 \\
\hline Nucleus drop & 0 & 0 \\
\hline Vitreous prolapse & 0 & 1 \\
\hline
\end{tabular}


Table-5 shows that the patients in group A experienced a low rate of complication. In all, 3 patients out of 50 had some complication, 1 patient had premature AC entry, 1 had extended capsulorrhexis while 1 patient had rent in the posterior capsule. However, no patient had a nucleus drop or vitreous prolapse and the overall complication rate was $6 \%$. Patients in group B also experienced a low rate of complication overall. In all, 4 patients out of 50 had some complication, 1 patient had premature AC entry, 1 had extended capsulorrhexis while 1 patient had rent in the posterior capsule and 1 patient had vitreous prolapse. However, no patient had a nucleus drop and the overall complication rate was $8 \%$.

Table-6: Postoperative complications in group A and group $B$

\begin{tabular}{|l|l|l|}
\hline \multirow{2}{*}{ Nature of complications } & \multicolumn{2}{|c|}{ Number of patients } \\
\cline { 2 - 3 } & Group A & Group B \\
\hline Subconjunctival hemorrhage & 1 & 1 \\
\hline Keratitis & 1 & 3 \\
\hline Retained lens matter & 1 & 1 \\
\hline Papillary block & 0 & 0 \\
\hline Sterile anterior uveitis & 0 & 0 \\
\hline Glaucoma & 0 & 0 \\
\hline Endophthalmitis & 0 & 0 \\
\hline
\end{tabular}

Table-6 shows that in group A, 3 patients in group A experienced some post- operative complications. 1 patient had subconjunctival hemorrhage, 1 experienced mild to moderate keratitis while 1 patient had some retained lens matter. The overall complication rate was $6 \%$. In group $\mathrm{B}, 5$ patients in group A experienced some post- operative complications. 1 patient had subconjunctival haemorrhage, 3 experienced mild to moderate keratitis while 1 patient had some retained lens matter. The overall complication rate was $10 \%$.

Table-7: Final visual outcomes in patients in group $A$ and group $B$ at 8 weeks

\begin{tabular}{|l|l|l|}
\hline \multirow{2}{*}{$\begin{array}{l}\text { Best corrected visual } \\
\text { acuity (snellen's) }\end{array}$} & \multicolumn{2}{|l|}{ Number of patients } \\
\cline { 2 - 3 } 6/6-6/6p & Group A & Group B \\
\hline $6 / 9-6 / 9 p$ & 22 & 26 \\
\hline $6 / 12-6 / 12 p$ & 19 & 16 \\
\hline $6 / 18-6 / 18 p$ & 9 & 6 \\
\hline $6 / 24-6 / 24 p$ & 0 & 2 \\
\hline $6 / 36-6 / 36 p$ & 0 & 0 \\
\hline $6 / 60$ and less & 0 & 0 \\
\hline
\end{tabular}

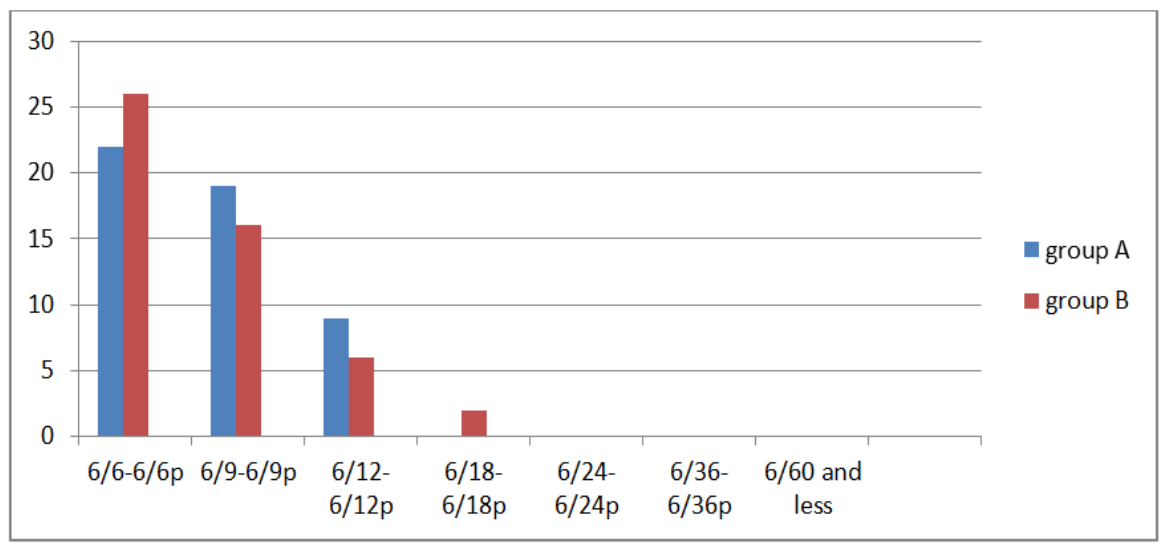

Fig-2: Final visual outcomes in patients in group $A$ and group $B$ at 8 weeks

Table-7 and Figure- 2 shows that in group A, at the end of 8 weeks, 22(44\%) patients had a visual acuity of $6 / 6 \mathrm{p}$ or better, $19(38 \%)$ had a visual acuity between 6/9-6/9p and 9(18\%) patients had a visual acuity between $6 / 12-6 / 12 \mathrm{p}$. In group $\mathrm{B}$, at the end of 8 weeks, $26(52 \%)$ patients had a visual acuity of $6 / 6$ p or better, $16(32 \%)$ had a visual acuity between 6/9-6/9p and $6(12 \%)$ patients had a visual acuity between $6 / 12$ $6 / 12 \mathrm{p}$ and $2(4 \%)$ had a visual acuity between 6/18$6 / 18 \mathrm{p}$.

\section{DiscussiON}

This study entitled "A Comparative Evaluation of Manual Small Incision Cataract Surgery and Phacoemulsification with Rigid Posterior Chamber Intraocular Lens" was carried out at Pt. B. D. Sharma
P.G.I.M.S., Rohtak. The study was carried out on 100 patients who were randomly and equally divided into two groups A and B of 50 patients each. In the patients of Group A, manual small incision cataract surgery with rigid posterior chamber intraocular lens was carried out and in patients of Group B phacoemulsification with rigid posterior chamber intraocular lens was carried out.

\section{Eye Operated}

$54 \%$ of the eyes operated in Group A were right eyes while $46 \%$ were left eyes, while the percentage in group B stood at $60 \%$ and $40 \%$ respectively. Guzek et al reported $44.5 \%$ right eyes and $55.5 \%$ left eyes and $37.5 \%$ right eyes and $62.5 \%$ left eyes in their study [21]. These figures are similar to our percentages. 


\section{Preoperative Astigmatism}

The mean preoperative astigmatism in Group A was $+0.98 \pm 0.68 \mathrm{D}$ with the rule and $-1.12 \pm 0.61 \mathrm{D}$ against the rule and in Group B it was $+1.09 \pm 0.72 \mathrm{D}$ with the rule and $-0.93 \pm 0.46 \mathrm{D}$ against the rule. This was comparable to that of Long and Monica in their study on a prospective evaluation of corneal curvature changes with 3.0 to $3.5 \mathrm{~mm}$ corneal tunnel phacoemulsification [22].

\section{Postoperative Astigmatism}

The mean postoperative astigmatism in Group A was $-0.88 \pm 0.52 \mathrm{D}$ in the with the rule sub group, $1.42 \pm 0.39 \mathrm{D}$ in the no astigmatism sub group, and $2.41 \pm 0.75 \mathrm{D}$ in the against the rule sub group. The mean postoperative astigmatism in Group B was -1.02 $\pm 0.63 \mathrm{D}$ in the with the rule sub group, $-1.40 \pm 0.46 \mathrm{D}$ in the no astigmatism sub group, and $-2.52 \pm 0.65 \mathrm{D}$ in the against the rule sub group. Bilinska et al in their study reported a mean postoperative astigmatism of $0.95 \mathrm{D}$ in their study on postoperative astigmatism after scleral tunnel phacoemulsification [23]. Zhang et al also reported a mean postoperative astigmatism of $1.24 \pm 0.93 \mathrm{D}$ at one month after phacoemulsification through a Sclera tunnel [24]. These results are comparable to that in our study. The unpaired t-test was used to compare the postoperative astigmatism between the two groups. The three sub groups i.e. preoperative with the rule astigmatism, astigmatically neutral, and against the rule astigmatism were compared separately. The difference between the postoperative astigmatism between the two groups was statically not significant ( $p>0.87, p>0.07, p>0.40$ across the three sub groups.

\section{Surgically Induced Astigmatism}

The mean surgically induced astigmatism in Group A was $1.40 \pm 0.30 \mathrm{D}$ in the with the rule sub group, $1.42 \pm 0.39 \mathrm{D}$ in the no astigmatism sub group, and $1.39 \pm 0.23 \mathrm{D}$ in the against the rule sub group. The mean surgically induced astigmatism in Group B was $1.6 \pm 0.4 \mathrm{D}$ in the with the rule sub group, $1.5 \pm 0.55 \mathrm{D}$ in the no astigmatism sub group, and $1.59 \pm 0.26 \mathrm{D}$ in the against the rule sub group. Sekundo et al [25] reported a mean post- operative induced astigmatism of $0.89 \pm 0.78 \mathrm{D}$ at the end of 4 weeks which is comparable to our study. Erich et al in their extensive study on induced astigmatism with self- sealing incisions reported a mean astigmatism of $0.94 \pm 0.73 \mathrm{D}$ in these cases, which is comparable to our study [26]. These results were also compared using unpaired t-test. The three sub groups i.e. preoperative with the rule astigmatism, astigmatically neutral, and against the rule astigmatism were compared separately. The difference between the surgically induced astigmatism between the two groups was statically not significant $(\mathrm{p}>1.24$, $p>0.07, p>1.97$ across the three sub groups).

\section{Operative Complications}

The overall complication rate in the study was 7.5\%. 3 patients (8\%) in group A had complications, 1 case of premature AC entry, 1 of extended capsulorrhexis and 1 case of posterior capsular rent, in group B, 4 patients (8\%) experienced complications, 1 case of premature entry, 1 of extended capsulorrhexis, 1 of posterior capsular rent and 1 case of vitreous prolapse. However, all cases were successfully managed with satisfactory visual outcome. Guzek et al., [21] reported a similar rate of complications in their study.

\section{Postoperative Complications}

The overall complication rate in the study was $8 \%$. 3 patients $(6 \%)$ in group A had complications while in group B, $10 \%$ experienced complications. Complications ranged from keratitis to subconjunctival hemorrhage and retained lens matter. However, all cases were managed on conservative therapy with satisfactory visual outcomes.

\section{Visual Outcome}

In group A, 41 patients had a best corrected visual acuity (BCVA) in the range of $6 / 6$ to $6 / 9$. No patient had a BCVA less than 6/12p. Similarly, in group B, 42 patients had a best corrected visual acuity (BCVA) in the range of $6 / 6$ to $6 / 9$. No patient had a BCVA less than 6/18p.

\section{Conclusion}

- Preoperatively from group A, 27 patients had with- the- rule astigmatism, 9 were astigmatically neutral and 14 had against- therule astigmatism. Similarly, preoperatively from group B, 26 patients had with- the- rule astigmatism, 13 were astigmatically neutral and 11 had against- the- rule astigmatism.

- The mean pre- operative astigmatism from group A was $+0.98 \pm 0.68 \mathrm{D}$ in the with- therule sub group and $-1.12 \pm 0.61 \mathrm{D}$ in the against- the- rule sub- group and from group $B$ it was $+1.09 \pm 0.72 \mathrm{D}$ in the with- the- rule sub group and $-0.93 \pm 0.46 \mathrm{D}$ in the against - the rule sub group.

- The mean post- operative astigmatism was as follows-

* In group A, in patients with pre- operative with- the- rule astigmatism it was $-0.88 \pm$ $0.52 \mathrm{D}$, in patients with preoperative astigmatic neutrality it was $-1.42 \pm 0.39$ $\mathrm{D}$, and in patients with preoperative against- the- rule astigmatism, it was -2.41 $\pm 0.75 \mathrm{D}$.

* In group B, in patients with pre- operative with- the- rule astigmatism it was $-1.02 \pm$ $0.63 \mathrm{D}$, in patients with preoperative astigmatic neutrality it was $-1.40 \pm 0.46$ $\mathrm{D}$, and in patients with preoperative 
against- the- rule astigmatism, it was -2.52 $\pm 0.65 \mathrm{D}$

- The mean surgically induced astigmatism was as follows-

* In group A, in patients with pre- operative with- the- rule astigmatism it was $1.40 \pm$ $0.30 \mathrm{D}$, in patients with preoperative astigmatic neutrality it was $1.42 \pm 0.39 \mathrm{D}$, and in patients with preoperative againstthe- rule astigmatism, it was $1.39 \pm 0.23$ D.

* In group B, in patients with pre- operative with- the- rule astigmatism it was $1.6 \pm$ $0.40 \mathrm{D}$, in patients with preoperative astigmatic neutrality it was $1.5 \pm 0.55 \mathrm{D}$, and in patients with preoperative againstthe- rule astigmatism, it was $1.59 \pm 0.26$ D.

- Operative complications were observed in 3 (6\%) patients from group A. 1 patient had premature anterior chamber entry, 1 had an extended capsulorrhexis and 1 had a rent in the posterior capsule. While in group B, Operative complications was observed in $4(8 \%)$ patients i.e. 1 patient had premature anterior chamber entry, 1 had an extended capsulorrhexis and 1 had a rent in the posterior capsule and 1 patient had vitreous prolapse. The overall operative complication rate was $7.5 \%$.

- The most common postoperative complication noted was keratitis. 1 patient in group $\mathrm{A}$ and 3 in group B had some degree of keratitis. All cases were managed conservatively and eventually had a good visual outcome. Apart from this. 1 patient in each groups $\mathrm{A}$ and $\mathrm{B}$ had sub- conjunctival hemorrhage, and 1 each showed retained lens matter. However, all patients had acceptable visual outcome. The overall postoperative complication rate in the study was $8 \%$.

\section{REFERENCE}

1. Swinger, C. A. (1987). Postoperative astigmatism. Survey of Ophthalmology, 31, 219-248.

2. Elder, D. (1999). Astigmatism. In: Abrams D ed. Duke Elder's Practice of Refraction, 10, 65-70.

3. Jaffe, N. S., \& Clayman, H. M. (1975). The pathophysiology of corneal astigmatism after cataract extraction. American Academy of Ophthalmology and Otolaryngology, 79, 615-630.

4. Hyde, L. (1978). Understanding corneal astigmatism in relation to anterior segment surgery. Current concepts in cataract surgery. Proceedings of sixth biennial cataract surgical congress, Toronto, London: CV Mosby Co, 1980.

5. Van Rij, G., \& Waring, G. O. (1984). Corneal curvature induced by sutures and incisions. American journal of ophthalmology, 98(6), 773783.
6. Eve, F. R., \& Troutman, R. C. (1976). Placement of sutures used in corneal incision. American journal of ophthalmology, 82(5), 786-789.

7. Dunnington, J. H. (1951). Healing of incisions for cataract extraction. American journal of ophthalmology, 34(1), 36-45.

8. Dowling, J. L. (1981). Wound closure in cataract surgery. Journal of Ophthalmology and Ophthalmic Surgery, 12(8), 574-577.

9. Troutman, R. C., \& Eve, F. R. (1973). Deep suturing of corneal incision. Journal of Ophthalmology and Ophthalmic Surgery, 4, 1622.

10. Samples, JR, Binder, PS. (1984). The value of the terry keratometer in predicting postoperative astigmatism. Ophthalmology, 91(3), 280-284.

11. Llliff, C. E., Eve, F. R. (1973). Deep suturing of corneal incision. Journal of Ophthalmology and Ophthalmic Surgery, 4, 16-22.

12. Jaffe, N. S. (1990). Cataract surgery and its complications. St. Louis: CV Mosby.

13. Kelman, C. D. (1967). Phacoemulsification and aspiration. American journal of ophthalmology, 64(1), 23-25.

14. Paulsen, A., \& Henning, V. (1993). Surgically induced astigmatism after small sclera pocket incision in phacoemulsification- horizontal vs radial suture closure. European journal of implant and refractive surgery, 5, 233-236.

15. Dam-Johannsen, M., Olsen, T., \& Theodorsen, F. (1994). The longterm course of surgically induced astigmatism after a scleral tunnel incision. European journal of implant and refractive surgery, 6, 334-342.

16. Lim, T. S., Gunning, F. P., \& Greve, E. L. (1992). Astigmatism following cataract surgery: comparison of a sclera and corneal incision in a mixed group of patients with and without glaucoma. International Ophthalmology, 16, 177 183.

17. Kohnen, T., Mann, P. M., Husain, S. E., Abarca, A., \& Koch, D. D. (1996). Corneal topographic changes and induced astigmatism resulting from superior and temporal scleral pocket incisions. Ophthalmic Surgery, Lasers and Imaging Retina, 27(4), 263-269.

18. Cravy, T. V. (1991). Routine use of temporal approach to cataract extraction to achieve rapid and sustained stabilization of postoperative astigmatism. Journal of Cataract and Refractive Surgery, 17, 415-423.

19. Sachdeva, M. S., Mishra, P., \& Thanikachalam, S. (2002). The manual small incision surgical aspect1. In: Kamaljeet, Sachdeva MS, editors. Small Incision Cataract Surgery (manual phaco). Delhi: Jaypee Brothers, 25.

20. Koch, P. S. (1991). Structural analysis of cataract incision construction. Journal of Cataract and Refractive Surgery, 17, 661-667. 
21. Guzek, J. P., \& Ching, A. (2003). Small incision manual extracapsular cataract surgery in Ghana, West Africa. Journal of Cataract and Refractive Surgery, 29(1), 57-64.

22. Long, D. A., \& Monica, M. I. (1996). A prospective evaluation of corneal curvature changes with 3.0 to $3.5 \mathrm{~mm}$ corneal tunnel phacoemulsification. Ophthalmology, 103(2), 226-232.

23. Bilinska, E., Wesolek-Czernik, A., Synder, A., \& Omulekci, W. (2004). Surgically induced astigmatism after cataract phacoemulsification. Klinika Oczna, 106(6), 756-759.
24. Zhang, Q., Sheng, Y., \& Li, Z. (2000). Analysis of postoperative astigmatism after phacoemulsification with intraocular lens implantation. Zhonghua Yan Ke Za Zhi, 36(6), 452-454.

25. Sekundo, W., Böker, T., \& Fimmers, R. (2000). Induced corneal astigmatism using an asymmetric corneoscleral tunnel and a large-optic intraocular lens. Journal of Cataract \& Refractive Surgery, 26(1), 79-82.

26. Erich C., Pham, D. T., Haberle, H., \& Wollensack, J. (1998). Cataract surgery at Virchow- Klinkum- Berlin: overview of the last 16 years. Ophthalmology, 95:423-427. 